\title{
Correction to: Budget impact of botulinum toxin treatment for spasticity after stroke - a German perspective
}

\author{
Silke Neusser ${ }^{1} \cdot$ Cordula Kreuzenbeck $^{2} \cdot$ Kathrin Pahmeier $^{2} \cdot$ Beate Lux $^{2} \cdot$ Alexander Wilke $^{3} \cdot$ Jürgen Wasem $^{2}$. \\ Anja Neumann ${ }^{2}$
}

Published online: 21 January 2021

(C) The Author(s) 2021

\section{Correction to: Journal of Public Health: From Theory to Practice https://doi.org/10.1007/s10389-019-01161-6}

The article "Budget impact of botulinum toxin treatment for spasticity after stroke - a German perspective", written by Silke Neusser, Cordula Kreuzenbeck, Kathrin Pahmeier, Beate Lux, Alexander Wilke, Jürgen Wasem and Anja Neumann, was originally published electronically on the publisher's internet portal on 28 November 2019 without open access. With the author(s)' decision to opt for Open Choice the copyright of the article changed on 23 December 2020 to (C) The Author(s) 2020 and the article is forthwith distributed under a Creative Commons Attribution 4.0 International License, which permits use, sharing, adaptation, distribution and reproduction in any medium or format, as long as you give appropriate credit to the original author(s) and the source, provide a link to the Creative Commons license, and indicate if changes were made. The images or other third party material in this article are included in the article's Creative Commons licensee, unless indicated otherwise in a credit line to the material. If material is not included in the article's Creative Commons license and your intended use is not

The online version of the original article can be found at https://doi.org/ 10.1007/s10389-019-01161-6

Anja Neumann

anja.neumann@medman.uni-due.de

1 Essener Forschungsinstitut für Medizinmanagement, Bredeneyer Str. 2b, 45133 Essen, Germany

2 Institute for Healthcare Management and Research, University of Duisburg-Essen, Thea-Leymann-Str. 9, 45127 Essen, Germany

3 Ipsen Pharma GmbH, Einsteinstraße 174, 81677 Munich, Germany permitted by statutory regulation or exceeds the permitted use, you will need to obtain permission directly from the copyright holder. To view a copy of this license, visit http://creativecommons.org/licenses/by/4.0.

The original article has been corrected.

Open Access This article is licensed under a Creative Commons Attribution 4.0 International License, which permits use, sharing, adaptation, distribution and reproduction in any medium or format, as long as you give appropriate credit to the original author(s) and the source, provide a link to the Creative Commons licence, and indicate if changes were made. The images or other third party material in this article are included in the article's Creative Commons licence, unless indicated otherwise in a credit line to the material. If material is not included in the article's Creative Commons licence and your intended use is not permitted by statutory regulation or exceeds the permitted use, you will need to obtain permission directly from the copyright holder. To view a copy of this licence, visit http://creativecommons.org/licenses/by/4.0/.

Publisher's note Springer Nature remains neutral with regard to jurisdictional claims in published maps and institutional affiliations. 